\title{
Bacteria, bile salts, and intestinal monosaccharide malabsorption
}

\author{
MICHAEL GRACEY ${ }^{1}$, VALERIE BURKE ${ }^{1}$, ADEMOLA OSHIN, JUDITH BARKER, \\ AND ERIC F. GLASGOW
}

From the Institute of Child Health, University of Birmingham, and Department of Pathology, Birmingham Children's Hospital, Birmingham, England

SUMMARY Intestinal monosaccharide transport was studied in a series of rats with a self-filling jejunal blind loop using $3 \mathrm{mM}$ arbutin (p-hydroxyphenyl-B-glucoside) or $1 \mathrm{mM}$ D-fructose as substrate in vitro and $10 \mathrm{mM}$ arbutin or $5 \mathrm{mM}$ D-fructose in vivo. These results were compared with changes in the bacterial flora and state of conjugation of intraluminal bile salts in those animals. Observations were also made of the microscopic and ultrastructural appearances of the smallintestinal epithelium.

In the small intestine of blind-loop rats intestinal monosaccharide transport is impaired, and in vitro is most marked in the blind loop, less so in the efferent jejunum, and not significantly altered in the afferent jejunum. A similar pattern of disturbed monosaccharide absorption was demonstrated by perfusions in vivo. The degree of the transport defect correlates closely with the luxuriance of the anaerobic flora, which averaged $10^{8}$ per millilitre in the blind loop, $10^{7}$ in the efferent jejunum, and $10^{6}$ in the afferent jejunum. A similar pattern of abnormality of bile salt conjugation occurred. In the blind loop the ratio of free to conjugated bile salts was grossly abnormal; this disturbance was somewhat less marked in the efferent jejunum and considerably less in the intraluminal contents of the afferent jejunum. An irregularly distributed lesion, consisting of swelling and vacuolation of microvilli and intracellular organelles, was demonstrated in the small-intestinal epithelium of blindloop animals.

Impaired absorption of monosaccharides is a further consequence of bacterial contamination of the upper gut. It is suggested that this defect is caused by the presence of high levels of deconjugated bile salts produced by an abnormal anaerobic bacterial flora in the small intestine.

The syndrome of temporary monosaccharide malabsorption in infancy was first documented only a few years ago (Burke and Danks, 1966) and has subsequently been reported from various parts of the world (Zetterström and Waldenström, 1968; Harries and Francis, 1968; Wharton, Howells, and Phillips, 1968; Coello-Ramírez, Gutíerrez-Topete, and Lifshitz, 1970; Lifshitz, Coello-Ramírez, and Gutíerrez-Topete, 1970a and b). The aetiology of this disorder, in which there is a temporary inability to absorb all dietary monosaccharides in the first weeks or months of life is not known. However, a similar form of transient malabsorption of simple dietary sugars occurs in some infants after small${ }^{1}$ Present address: Gastroenterological Research Unit, Princess Margaret Hospital Research Foundation, Perth, Western Australia

Received for publication 30 June 1971. intestinal surgery in the first month of life when the absorptive defect is associated with a luxuriant overgrowth of faecal organisms in the upper small intestine (Burke and Anderson, 1966). Two recent reports indicate that similar bacteriological changes occur in patients not previously subjected to surgery (Gracey, Burke, and Anderson, 1969; CoelloRamírez et al, 1970). The earlier of these reports showed the bacteriological abnormality to coincide with deconjugation of intraluminal bile salts; the authors suggested that this was due to the presence of an undetected abnormal anaerobic flora because of the almost exclusive ability of these organisms to deconjugate bile salts (Hill and Drasar, 1968). They further suggested that bacterial deconjugation of bile salts was closely related to the development of the monosaccharide transport defect. 
The present study examines the hypothesis that bacterial overgrowth and subsequent deconjugation of bile salts in the upper small intestine results in impaired monosaccharide absorption in rats with a jejunal blind loop in vitro and in vivo. Studies of the morphology of the small intestine in these animals were also performed.

Two substrates were chosen for these experiments. The first, arbutin (p-hydroxyphenyl- $\beta$-glucoside) is a synthetic analogue of $\mathrm{D}$-glucose and is actively transported by the small intestine of the rat in the same way as glucose. Since it is not metabolized (Alvarado and Crane, 1964) it is convenient, appropriate, and recognized material for the study of the intestinal active sugar transport process (Gracey, Burke, and Oshin, 1971a). The other, D-fructose, was included because of its involvement in the clinical syndrome of temporary monosaccharide malabsorption and its probable normal passage across the small intestine by a carrier mechanism separate from that for D-glucose and other actively transported sugars.

\section{Materials and Methods}

The experimental model used was the rat with a self-filling jejunal blind loop. Litter mates were used as controls. The blind loops were made surgically, then after two to three months the animals were studied by estimating faecal fat excretion over a period of five days; direct sampling and then examination of the aerobic and anaerobic bacterial flora of the jejunum (including the blind loop); ascertaining the pattern of conjugation of intraluminal jejunal bile salts by thin-layer chromatography; light and electron microscopy of the small intestine; and studying the uptake in vitro and absorption in vivo by the small intestine of a nonmetabolized analogue of D-glucose and D-fructose.

The significance of these results was assessed by performing control studies in normal animals and comparing the results by standard statistical methods.

\section{ANIMALS}

Adult Wistar rats weighing $150-300 \mathrm{~g}$ were used throughout. The operative procedure was done under light open-ether anaesthesia using the technique of Cameron, Watson, and Witts (1949) which creates a self-filling jejunal blind loop about $8 \mathrm{~cm}$ long and maintains intestinal continuity through a side-to-end anastomosis.

FAECAL FAT EXCRETION

Stool collections were made while animals were individually housed in cages with raised floors of wide-mesh wire netting to prevent coprophagy. In the operated animals this was done two months after operation. Stool fat excretion was estimated by the method of van de Kamer, ten Bokkel, Huinink, and Weyers (1949). The same animals were used for faecal fat excretion studies and studies of intestinal sugar transport.

\section{BACTERIOLOGICAL METHODS}

Samples were taken from the upper third of the jejunum of normal animals and in the blind-loop animals either by aspirating directly or syringing and then aspirating the area studied with sterile buffer while the animal was lightly anaesthetized or by draining the appropriate area immediately after sacrificing the animal. Appropriate correction was made for the dilution factor involved. In the case of the blind-loop rats, specimens were obtained from the blind loop itself and from the $10 \mathrm{~cm}$ of jejunum immediately proximal to (ie, afferent) or distal from (ie, efferent) the junction with the blind loop. Specimens were either cultured within two hours of collection or deep-frozen at $-20^{\circ}$ to $-60^{\circ}$ $\mathrm{C}$ in $2 \mathrm{ml}$ of transport medium $(1.8 \mathrm{ml}$ of glucose broth and $0.2 \mathrm{ml}$ of glycerol) until cultured within one month of collection. Serial dilution was done before plating on horse blood agar (routine and anoxic), MacConkey agar, Sabouraud dextrose agar, and the medium of de Man, Rogosa, and Sharpe (1960). Anaerobic blood agar plates were incubated under strict anaerobic conditions at $37^{\circ} \mathrm{C}$ for up to six days. Organisms isolated on anaerobic plates were subcultured onto aerobic blood agar plates to exclude facultative anaerobes. Results are expressed as the $\log _{10}$ of the mean viable counts per millilitre of specimen.

\section{BILE SALT ASSAYS}

Specimens for bile salt assays were taken in the same way as those for bacteriological studies. In the normal animals specimens were taken from the upper, middle, and lower thirds of the jejunum; in the blind-loop animals from the same areas as the bacteriological specimens.

Bile salts were assayed using the sulphuric acid method (Sjövall, 1959) as described by Poley, Dower, Owen, and Stickler (1964) and modified by the use of thin-layer chromatography instead of paper chromatography. The solvent system, chloroform; methanol; acetic acid (80:12:3 by volume), was used and gave satisfactory separation of the principal conjugated bile salts, taurocholate and glycocholate, from the unconjugated salts, cholate and deoxycholate. Standard bile salts were obtained from Maybridge Chemical Company, Cornwall. Standards of taurocholate, glycocholate, deoxy- 
cholate, and cholate were run on each thin-layer plate and the percentage recovery of these was determined. Recovery rates ranged from 70 to $75 \%$ for individual samples. The figures used in the correction, before expressing the results from each sample, were determined by the degrees of recovery of the internal standards used.

Taurocholate and glycocholate were assayed jointly but cholate and deoxycholate were each determined separately. Because of the inaccuracy of the method we did not attempt to determine concentrations of bile salts present in smaller amounts, such as chenodeoxycholate and its conjugates. To facilitate comparison between different animals and different areas of intestine, results are also expressed as a ratio of cholate and deoxycholate to taurocholate and glycocholate.

\section{LIGHT AND ELECTRON MICROSCOPY}

Specimens for light microscopy were fixed in formolsaline and carefully orientated before mounting and staining with haematoxylin and eosin.

In three rats $1 \mathrm{~mm}$ cubes of tissue were fixed in $5 \%$ glutaraldehyde for 90 minutes, then transferred to sodium cacodylate-sucrose buffer for two days and postfixed in $2 \%$ osmium tetroxide buffered with veronal acetate. Specimens were then processed through dehydration in graded ethanols to embedding in Epon. Using a Reichert OMU2 ultratome, sections $1 \mu$ thick were cut from blocks for identification and stained with toluidine blue. The blocks were trimmed appropriately, ultra-thin sections obtained and mounted on uncoated grids. They were stained with uranyl acetate and lead citrate and viewed in an AEI EM 6B electron microscope.

\section{UPTAKE AND PERFUSION STUDIES}

The uptake studies in vitro were done using the method described by Semenza and Mülhaupt (1969) which measures the uptake of substrate by everted pieces of tissue secured in a plexiglass tissue-holding apparatus.

For the perfusion studies in vivo the animals were lightly anaesthetized throughout the procedure with open ether. In normal animals a segment of midjejunum of $20 \mathrm{~cm}$ was used; in blind loop animals the afferent and efferent jeiunum immediately proximal to and distal from the junction with the blind loop were used respectively. Particular care was taken to maintain the vascular integrity of the segment when preparing for perfusion. After ligating the common bile duct proximal and distal polythene cannulae (external diameter $3.5 \mathrm{~mm}$ internal diameter $2.0 \mathrm{~mm}$ ) were introduced into the lumen of the gut through transverse incisions in its wall and secured by black silk ligatures so that a segment of approximately $20 \mathrm{~cm}$ in length could be perfused with a constant-rate perfusion apparatus at $10 \mathrm{ml}$ per hour in a peristaltic direction. The cannulae were exteriorized, the perfused segment was returned to the abdominal cavity, and the abdominal wall closed by metal clamps during the perfusion. The first 30 minutes of the perfusion were used for equilibration conditions to be achieved; during the second 30 minutes the perfusate was collected continuously. At the end of the experiment the perfused segment was removed and its length measured, always by one of us (M.G.), by suspending the tissue lengthwise with a constant weight $(25 \mathrm{~g})$ attached to the lower end. For technical and anatomical reasons it is not possible to study absorption by the blind loop itself in vivo.

SOLUTIONS USED FOR INCUBATIONS AND PERFUSIONS

The incubation media and perfusates were based on Krebs-Henseleit (1932) bicarbonate buffer at

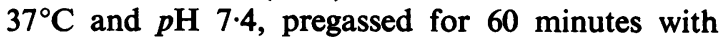
$95 \% \mathrm{O}_{2}$ and $5 \% \mathrm{CO}_{2}$ immediately before the experiments and gassed throughout the incubations with the same gaseous mixture. For incubations in vitro, $3 \mathrm{mM}$ arbutin (parahydroxyphenyl- $\beta$ glucoside) or $1 \mathrm{mM} D$-fructose was added to the solutions; at these concentrations accumulation against a concentration gradient has been demonstrated under similar conditions in vitro (Gracey, Burke, and Oshin, 1970 and 1971a). For the perfusions in vivo, the substrate concentrations were $10 \mathrm{mM}$ arbutin and $5 \mathrm{mM}$ D-fructose; at such concentrations significant inhibition of substrate absorption in vivo should be detectable by the analytical methods to be outlined.

Solutions containing D-fructose had $0.067 \mu \mathrm{Ci} / \mathrm{ml}$ of ${ }^{14} \mathrm{C}$-D-fructose added as marker. Solutions for incubations in vitro with $\mathrm{D}$-fructose also had $0.002 \mu \mathrm{moles} / \mathrm{ml}$ of ${ }^{3} \mathrm{H}$-mannitol added to estimate the amount of sugar entering the tissue by passive diffusion (Bihler and Crane, 1962); this index was subtracted from the fructose uptake figures. A similar correction factor was applied to the arbutin uptake figures by estimating the extent of passive diffusion of 2-deoxy-D-glucose included in the incubation medium at a concentration of $1.5 \mathrm{mM}$.

After incubation in D-fructose the tissues were homogenized in distilled water at $100^{\circ} \mathrm{C}$ for five minutes and the extracts subjected to liquid scintillation counting. Possible conversion of D-fructose to D-glucose or lactate during incubation or perfusion was checked in the extracts and perfusates respectively on thin-layer chromatography using the solvent system, n-propanol: acetic acid: water (14:1:1 by volume), and estimating the degree of 
recovery of fructose in relation to the total counts obtained from all these areas then examined separately by liquid scintillation counting. From the extracts following incubations in vitro $80 \%$ of radioactivity was recovered as D-fructose, the remainder being transferred to lactate. In the perfusates, following perfusion in vivo, $97 \%$ of total radioactivity was associated with D-fructose. Appropriate corrections for these figures were made when expressing the results. Polyethylene glycol $\mathbf{4 0 0 0}$ was used in all perfusion experiments as a non-absorbable marker and corrections for changes in volume were made when calculating the results. Results are expressed as $\mu$ moles of substrate accumulated per millilitre of tissue water for the experiments in vitro, assuming a tissue water content of $80 \%$ (Crane and Mandelstam, 1960). For the perfusion experiments the results are expressed as $\mu$ moles of substrate transported per centimetre of intestine per hour.

\section{CALCULATION OF DATA}

Standard arithmetical methods were used throughout in achieving means and standard deviations (SD). Student's $t$ test was used to obtain levels of statistical significance, and $P$ values of $<0.05$ are taken as being significant.

\section{ANALYTICAL METHODS}

Arbutin, from Sigma Chemical Co, St Louis, USA, was determined as free phenol (Lowry, Rosebrough, Farr, and Randall, 1951; Folin and Ciocalteu, 1959); polyethylene glycol (Hopkin and Williams, Chadwell Heath) by a micro-modification of Hydén's method (1956); 2-deoxy-D-glucose (Sigma Chemical Company, St Louis, USA) was determined by the formation of malonic dialdehyde with periodate and on its condensation with barbituric acid (Waravdekar and Saslaw, 1957).

Radioisotopes were obtained from the Radiochemical Centre, Amersham. The radiochemical purity of ${ }^{14} \mathrm{C}$-D-fructose was $99 \%$ and of ${ }^{3} \mathrm{H}$-mannitol was $99 \%$. Efficiency of liquid scintillation counting (Tracerlab CM-100 Spectrometer, London) was $85 \%$ for ${ }^{14} \mathrm{C}$ and $50 \%$ for ${ }^{3} \mathrm{H}$.

Acids, solvents, and other chemicals were obtained from British Drug Houses, Poole.

\section{Results}

\section{STOOL FAT EXCRETION}

The mean daily stool fat excretion in normal animals $(\mathrm{n}=24)$ was $194( \pm 1 \mathrm{SD}, 71) \mathrm{mg}$ (range $=104-272$ $\mathrm{mg})$. The operated animals $(\mathrm{n}=15)$ developed steatorrhoea, with a mean daily faecal fat excretion of $540( \pm 1 \mathrm{SD}, 160) \mathrm{mg}(\mathrm{P}<0.001$, range $=320$ $840 \mathrm{mg}$ ).

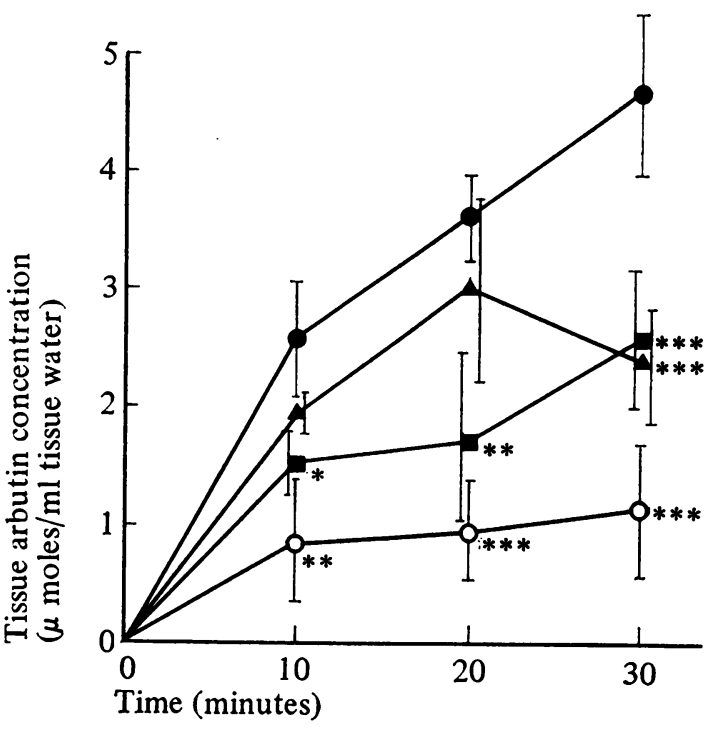

Fig. 1 Uptake of arbutin by small intestine of normal and blind-loop rats in vitro following incubation in a medium containing $3 \mathrm{mM}$ arbutin $(O=$ normal, $n=8$;

$\Delta=$ afferent jejunum of blind-loop rats, $n=5$;

$=$ efferent jejunum of blind-loop rats, $n=5 ; 0=$ blind-loops, $n=5$ ). Results show mean uptakes and one standard deviation. Statistical comparison with nornal uptake is indicated by asterisks; * indicates $\mathrm{P}<0.05, * *$ indicates $\mathrm{P}<0.01$, and *** indicates $\mathbf{P}<0.001$.

SUGAR UPTAKE in vitro

Using $3 \mathrm{mM}$ arbutin as substrate the mean uptake in normal animals was $2.6( \pm 1 \mathrm{SD}, 0.5) \mu \mathrm{moles} / \mathrm{ml}$ tissue water at 10 minutes and at 30 minutes was 4.7 $( \pm 1 \mathrm{SD}, 0.8)$. The rate of uptake was less in all segments studied from the blind-loop animals, and after $\mathbf{3 0}$ minutes the mean uptake was significantly less than the control values. The results after this time were for afferent gut $2.4( \pm 1 \mathrm{SD}, 0.5, \mathrm{P}<$ $0.001)$, blind-loop, $1.2( \pm 1 \mathrm{SD}, 0.6, \mathrm{P}<0.001)$, and for efferent gut $1.9( \pm 1 \mathrm{SD}, 0.6, \mathrm{P}<0.001)$ (Fig. 1).

With $1 \mathrm{mM}$ D-fructose as substrate the mean uptake in normal animals was $0.5( \pm 1 \mathrm{SD}, 0.2)$ $\mu \mathrm{moles} / \mathrm{ml}$ tissue water at 15 minutes, $0.9( \pm 1 \mathrm{SD}$, $0.2)$ at 30 minutes, $1.3( \pm 1 \mathrm{SD}, 0.3)$ at 45 minutes, and $1.4( \pm 1 \mathrm{SD}, 0.3)$ at 60 minutes. The rate of uptake of D-fructose was less in all three areas from the blind-loop animals. After incubation for 30 minutes and longer all these results were significantly less than normal (Fig. 2).

SUGAR TRANSPORT in vivo

Using $10 \mathrm{mM}$ arbutin as substrate, the jejunum of 


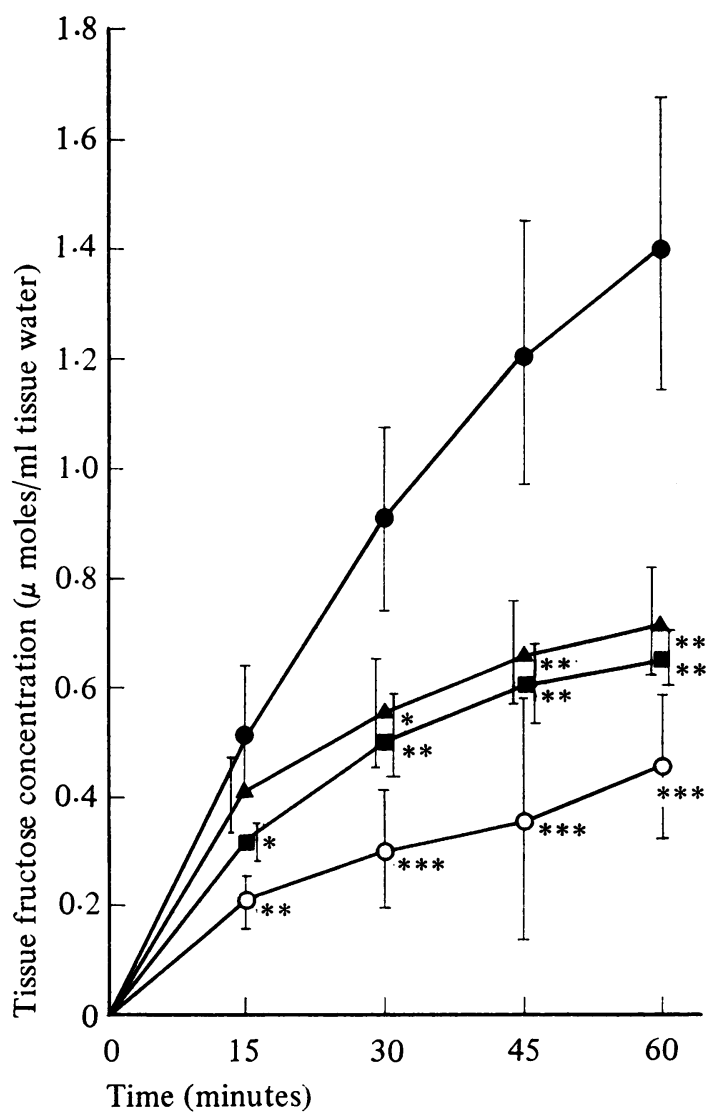

Fig. 2 Uptake of fructose by small intestine of normal and blind-loop rats in vitro, following incubation in a medium containing $1 \mathrm{mM} d$-fructose $(0=$ normal, $n=5$; $\Delta=$ afferent jejunum of blind-loop rats, $n=5$; $=$ efferent jejunum of blind-loop rats, $n=5 ; 0=$ blind loops, $n=5$ ). Results show mean uptakes and one standard deviation. Statistical comparison with normal uptake is indicated by asterisks; * indicates $\mathrm{P}<0.05, * *$ indicates $\mathrm{P}<0.01$, and ${ }^{* * *}$ indicates $\mathbf{P}<0.001$. normal animals transported 2.02 ( \pm 1 SD, 0.27) $\mu \mathrm{moles} / \mathrm{cm} /$ hour. Less was transported by the blind loop animals; in the afferent jejunum the decrease was not significant but in the efferent jejunum the result was highly significant (Table I).

With $5 \mathrm{mM}$ D-fructose as substrate the mean normal rate of intestinal transport was $0.016 \mu$ moles/ $\mathrm{cm} /$ hour. The rate of transport was less in both the afferent and efferent jejunum from the blind-loop rats. However, because of the small number of observations the statistical significance of these differences cannot be assessed.

BACTERIAL FLORA

These results are shown in detail in Table II. In normal rats the aerobic population was less than $10^{5}$ viable organisms per $\mathrm{ml}$ and the anaerobicpopulation was less than $10^{6}$ per $\mathrm{ml}$. In all three areas from blindloop rats there was an increase in both aerobes and anaerobes; the flora was most luxuriant in specimens from the blind loops. The changes were least marked in the afferent jejunum.

BILE SALTS

The quantitative bile salt levels are given in Table III. This shows a marked difference in the amounts of conjugated and unconjugated bile salts from jejunal contents of normal and blind-loop animals. In all three areas studied in blind-loop rats there was a significant decrease in the levels of conjugated bile salts and a corresponding increase in the levels of deconjugated bile salts. If expressed as a ratio of free (unconjugated) to conjugated bile salts the following patterns emerge: in normal rats this ratio is less than 1 ; in specimens taken from all areas of blind-loop rats this ratio was exceeded. The free/ conjugated ratios were highest in the blind loop $(6: 1)$ and more than $4: 1$ in the efferent jejunum.

\section{SMALL INTESTINAL MORPHOLOGY}

Light microscopy of the three areas from the blindloop animals showed no apparent morphological disturbances of the epithelial surface. There was a

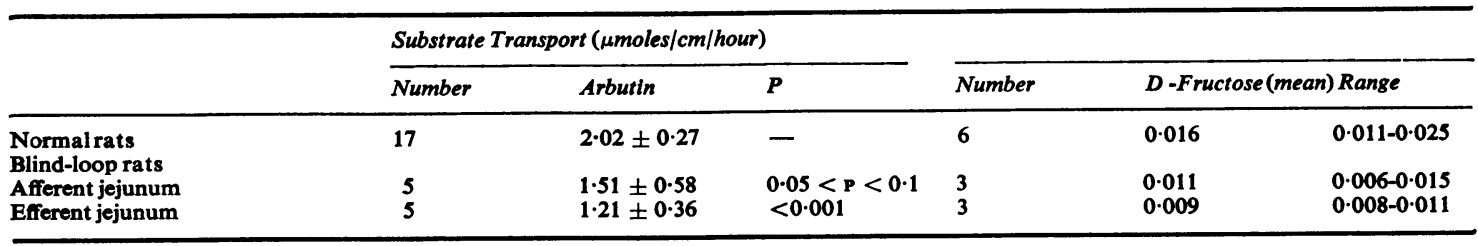

Table I Intestinal sugar transport by normal and blind-loop rats in vivo

${ }^{1}$ Perfusate contained $10 \mathrm{mM}$ arbutin or $5 \mathrm{mM}$ D-fructose respectively. 


\begin{tabular}{|c|c|c|c|c|c|c|c|c|c|c|c|c|c|}
\hline \multirow[t]{3}{*}{ Specimen } & \multirow[t]{3}{*}{ No. } & \multicolumn{8}{|l|}{ Aerobes } & \multicolumn{4}{|c|}{ Anaerobes } \\
\hline & & \multicolumn{2}{|c|}{ Enterobacteria } & \multirow{2}{*}{$\begin{array}{l}\text { Entero- } \\
\text { cocci }\end{array}$} & \multirow{2}{*}{$\begin{array}{l}\alpha- \\
\text { Haemo- } \\
\text { lytic } \\
\text { Strepto- } \\
\text { cocci }\end{array}$} & \multicolumn{2}{|c|}{ Staphylococci } & \multirow{2}{*}{$\begin{array}{l}\text { Lacto- } \\
\text { bacilli }\end{array}$} & \multirow[t]{2}{*}{ Total } & \multirow{2}{*}{$\begin{array}{l}\text { Bacter- } \\
\text { oides }\end{array}$} & \multirow{2}{*}{$\begin{array}{l}\text { Bifido- } \\
\text { bacteria }\end{array}$} & \multirow{2}{*}{$\begin{array}{l}\text { Clos- } \\
\text { tridia }\end{array}$} & \multirow[t]{2}{*}{ Total } \\
\hline & & E. coli & Others & & & $\begin{array}{l}\text { Coagul- } \\
\text { ase } \\
\text { +ve }\end{array}$ & $\begin{array}{l}\text { Coagul- } \\
\text { ase } \\
\text {-ve }\end{array}$ & & & & & & \\
\hline Normal rats & 9 & $\begin{array}{l}2 \cdot 5 \\
(0-3 \cdot 5)\end{array}$ & - & $\begin{array}{l}2 \cdot 8 \\
(0-3 \cdot 8)\end{array}$ & - & $\begin{array}{l}3 \cdot 4 \\
(0-4 \cdot 1)\end{array}$ & $\begin{array}{l}4 \cdot 0 \\
(0-4 \cdot 8)\end{array}$ & $\begin{array}{l}4 \cdot 1 \\
(0-5 \cdot 0)\end{array}$ & $\begin{array}{l}4 \cdot 2 \\
(0-5 \cdot 0)\end{array}$ & - & $\begin{array}{l}5 \cdot 6 \\
(0-6 \cdot 6)\end{array}$ & $\begin{array}{l}5 \cdot 6 \\
(0-6 \cdot 6)\end{array}$ & $\begin{array}{l}5 \cdot 9 \\
(0-6 \cdot 9)\end{array}$ \\
\hline $\begin{array}{l}\text { Blind-loop rats } \\
\text { Afferent jejunum }\end{array}$ & 14 & $\begin{array}{l}5 \cdot 1 \\
(0-7 \cdot 2)\end{array}$ & $\begin{array}{l}4 \cdot 4 \\
(0-4 \cdot 5)\end{array}$ & $\begin{array}{l}4 \cdot 4 \\
(0-4 \cdot 7)\end{array}$ & $\begin{array}{l}4 \cdot 6 \\
(0-5 \cdot 7)\end{array}$ & $\begin{array}{l}2 \cdot 4 \\
(0-3 \cdot 6)\end{array}$ & $\begin{array}{l}4 \cdot 1 \\
(0-5 \cdot 2)\end{array}$ & $\begin{array}{l}3 \cdot 1 \\
(0-4 \cdot 1)\end{array}$ & $\begin{array}{l}5 \cdot 4 \\
(3 \cdot 8-7 \cdot 2)\end{array}$ & $\begin{array}{l}5 \cdot 4 \\
(0-6 \cdot 3)\end{array}$ & $\begin{array}{l}6 \cdot 3 \\
(0-6 \cdot 9)\end{array}$ & $\begin{array}{l}4 \cdot 4 \\
(0-5 \cdot 4)\end{array}$ & $\begin{array}{l}6 \cdot 3 \\
(0-6.9)\end{array}$ \\
\hline Blind loop & 14 & $\begin{array}{l}6 \cdot 1 \\
(4 \cdot 8-7 \cdot 7)\end{array}$ & $\begin{array}{l}5 \cdot 8 \\
(0-6.9)\end{array}$ & $\begin{array}{l}6 \cdot 3 \\
(0-7 \cdot 3)\end{array}$ & $\begin{array}{l}4 \cdot 4 \\
(0-5 \cdot 5)\end{array}$ & $\begin{array}{l}2 \cdot 2 \\
(0-3 \cdot 3)\end{array}$ & $\begin{array}{l}6 \cdot 5 \\
(0-7 \cdot 4)\end{array}$ & $\begin{array}{l}5 \cdot 1 \\
(0-6 \cdot 0)\end{array}$ & $\begin{array}{l}7 \cdot 3 \\
(4 \cdot 9-7 \cdot 9)\end{array}$ & $\begin{array}{l}8 \cdot 1 \\
(0-8 \cdot 9)\end{array}$ & $\begin{array}{l}7 \cdot 7 \\
(6 \cdot 4-8 \cdot 2)\end{array}$ & $\begin{array}{l}3 \cdot 9 \\
(0-4 \cdot 8)\end{array}$ & $\begin{array}{l}8 \cdot 2 \\
(6 \cdot 4-8 \cdot 9)\end{array}$ \\
\hline Efferent jejunum & 14 & $\begin{array}{l}6 \cdot 6 \\
(0-7 \cdot 3)\end{array}$ & $\begin{array}{l}5 \cdot 2 \\
(0-6 \cdot 3)\end{array}$ & $\begin{array}{l}5 \cdot 2 \\
(0-5 \cdot 9)\end{array}$ & $\begin{array}{l}4 \cdot 5 \\
(0-5 \cdot 6)\end{array}$ & $\begin{array}{l}2 \cdot 5 \\
(0-3 \cdot 6)\end{array}$ & $\begin{array}{l}5 \cdot 0 \\
(0-6 \cdot 1)\end{array}$ & $\begin{array}{l}5 \cdot 4 \\
(0-6 \cdot 5)\end{array}$ & $\begin{array}{l}6 \cdot 7 \\
(3 \cdot 9-7 \cdot 3)\end{array}$ & $\begin{array}{l}6 \cdot 7 \\
(0-7 \cdot 6)\end{array}$ & $\begin{array}{l}6 \cdot 9 \\
(0-7 \cdot 9)\end{array}$ & $\begin{array}{l}4 \cdot 8 \\
(0-5 \cdot 8)\end{array}$ & $\begin{array}{l}7 \cdot 1 \\
(0-8 \cdot 1)\end{array}$ \\
\hline
\end{tabular}

Table II Intestinal bacterial flora of normal and blind-loop rats ${ }^{1}$

${ }^{1}$ Results indicate mean populations of individual species and total flora expressed as the $\log _{10}$ of the mean viable count per ml of specimens. The range of results is shown in parentheses.

\begin{tabular}{|c|c|c|c|c|c|}
\hline \multirow[t]{2}{*}{ Bile Salt } & \multicolumn{2}{|l|}{ Normal Rats (5) } & \multicolumn{3}{|c|}{ Blind-loop Rats (6) } \\
\hline & Specimens from & $\begin{array}{l}\text { Bile Salt Level } \\
\text { (رmoles/ml) }\end{array}$ & Specimens from & $\begin{array}{l}\text { Bile Salt Level } \\
\text { ( } \mu \text { moles/ml) }\end{array}$ & p value \\
\hline Taurocholate + glycocholate & $\begin{array}{l}\text { Upper } \\
\text { Middle } \\
\text { Lower }\end{array}$ & $\begin{array}{r}11.9 \pm 1.2 \\
13.6 \pm 2.4 \\
8.3 \pm 1.8\end{array}$ & $\begin{array}{l}\text { Afferent } \\
\text { Blind loop } \\
\text { Efferent }\end{array}$ & $\begin{array}{l}6.7 \pm 1.9 \\
2.2 \pm 1.5 \\
2.4 \pm 0.4\end{array}$ & $\begin{array}{l}<0.001 \\
<0.001 \\
<0.001\end{array}$ \\
\hline Cholate & $\begin{array}{l}\text { Upper } \\
\text { Middle } \\
\text { Lower }\end{array}$ & $\begin{array}{l}0.2 \pm 0.1 \\
2.0 \pm 0.5 \\
2.8 \pm 0.5\end{array}$ & $\begin{array}{l}\text { Afferent } \\
\text { Blind loop } \\
\text { Efferent }\end{array}$ & $\begin{array}{l}2.9 \pm 1.6 \\
8.6 \pm 1.8 \\
7.6 \pm 2.1\end{array}$ & $\begin{array}{l}<0.005 \\
<0.001 \\
<0.005\end{array}$ \\
\hline Deoxycholate & $\begin{array}{l}\text { Upper } \\
\text { Middle } \\
\text { Lower }\end{array}$ & $\begin{array}{l}0.1 \pm 0.1 \\
0.3 \pm 0.1 \\
0.8 \pm 0.2\end{array}$ & $\begin{array}{l}\text { Afferent } \\
\text { Blind loop } \\
\text { Efferent }\end{array}$ & $\begin{array}{l}1.2 \pm 0.4 \\
3.6 \pm 1.4 \\
3.2 \pm 1.1\end{array}$ & $\begin{array}{l}<0.001 \\
<0.001 \\
<0.005\end{array}$ \\
\hline
\end{tabular}

Table III Quantitative bile salt levels in jejunal intraluminal contents from normal and blind-loop rats

greater than normal degree of cellular infiltration of the lamina propria, predominantly by plasma cells and lymphocytes.

Electron-microscopic examination revealed an irregularly distributed pattern of ultramicroscopic changes in the epithelium of the blind loop and distal gut areas. This change, shown in Figs. 3 and 4, demonstrates 'blistering' or 'ballooning' of the microvilli associated with underlying mitochondrial swelling in the affected cells. A characteristic feature of these lesions was their apparent confinement to isolated cells which often adjoined cells of normal appearance.

\section{Discussion}

The studies reported here were prompted by recent clinical experience with young infants with the syndrome of temporary monosaccharide malabsorption, where an abnormal small-intestinal bacterial flora and bile salt deconjugation are associated with a temporary inability to absorb all dietary monosaccharides (Gracey et al, 1969). In the present experiments impaired intestinal transport of two monosaccharides has been demonstrated in vitro and in vivo in rats with a surgically constructed, self-filling jejunal blind loop. One of the substrates used (arbutin) is normally carried by the established intestinal active sugar transport pathway (Alvarado and Crane, 1964): the other, D-fructose, is probably carried by a different mechanism. Along with this impairment of carbohydrate absorption were found a grossly abnormal aerobic and anaerobic smallintestinal bacterial flora, extensive deconjugation of intraluminal bile salts, and ultrastructural changes in the epithelial cells of the small intestine.

Intestinal sugar transport was markedly impaired in vitro in tissue from the blind loop and the intestine immediately distal to it. This inhibitory effect was present, but less marked, in jejunum proximal to the blind loop. A previous study has shown everted sacs of small intestine of blind-loop rats have impaired absorption of glucose in vitro (Baraona, Palma, Navia, Salinas, Orrego, and Espinoza, 1968), but direct evidence of impaired carbohydrate absorption has not previously been found in vivo. That impaired intestinal sugar transport occurs in blind-loop rats in vivo was clearly shown in the 


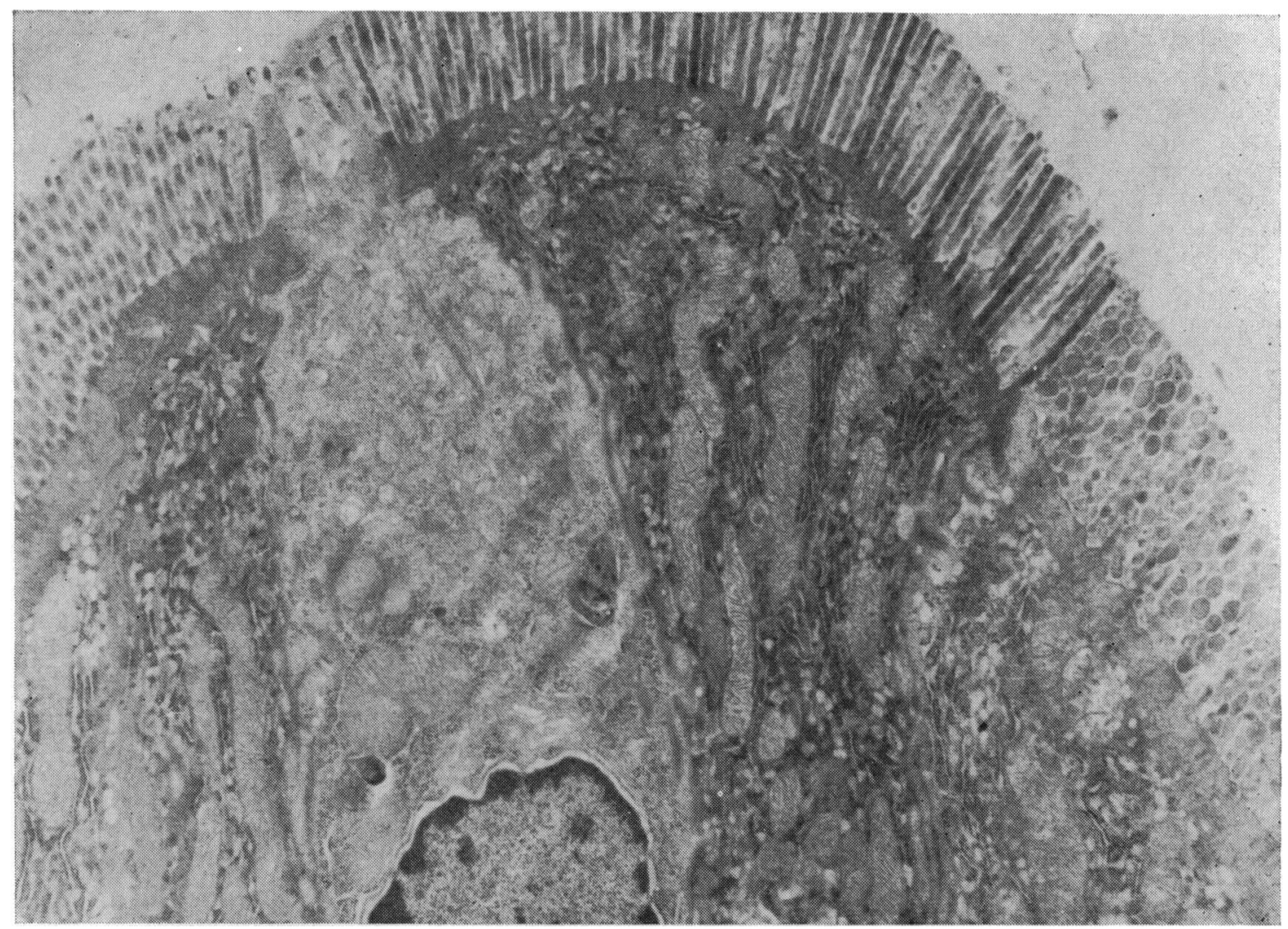

Fig. 3 Electron micrograph of small-intestinal epithelial surface from a blind-loop animal illustrating two normal epithelial cells with a goblet cell between them and an abnormal epithelial cell on the right. The latter has swollen, poorly staining mitochondria and cytoplasmic inclusions of less than normal density. The overlying microvilli are 'ballooned' and poorly staining. The microvilli overlying the normal cell on the left are cut tangentially and illustrate the differences in morphology and staining characteristics between these and the 'ballooned' microvilli overlying the abnormal cell $(\times 4000)$.

present study where absorption of arbutin was significantly depressed in small intestine distal to the blind loop. Although the numbers of experiments with D-fructose are too small to make statistically valid comment, there was a similar trend shown with this substrate. These findings suggest that disturbance of the intestinal active sugar transport pathway and that involved in the transport of D-fructose occurs as a consequence of bacterial contamination of the upper gut.

The pathogenesis of disturbed carbohydrate absorption in this situation is not clear. Blind-loop rats have previously been shown to have impaired urinary excretion of D-xylose (Donaldson, 1967) but the degree of intraluminal consumption of the sugar by bacteria was unknown and cast doubts on the pathogenesis of the absorptive defect. This proposed mechanism of apparently artefactual dis- appearance of the sugar has since been supported by others (Goldstein, Karacadag, Wirts, and Kowlessar, 1970). However, its clinical significance, in quantitative terms, remains doubtful and evidence against the importance of bacterial utilization in vivo comes from acute experiments in blind-loop rats in which previous clearing of the gut lumen of bacteria does not reverse the $D$-xylose absorptive defect (R. M. Donaldson Jr, 1970, personal communication)

How might impaired monosaccharide absorption develop in this situation? The present data show close correlation of the severity of the absorptive defect with the degree of abnormality of the intestinal bacterial flora and the extent of deconjugation of bile salts, which was most marked in the contents of the blind loop and less so, but still very considerable, in the contents of the efferent jejunum. There is now considerable evidence available which suggests that 


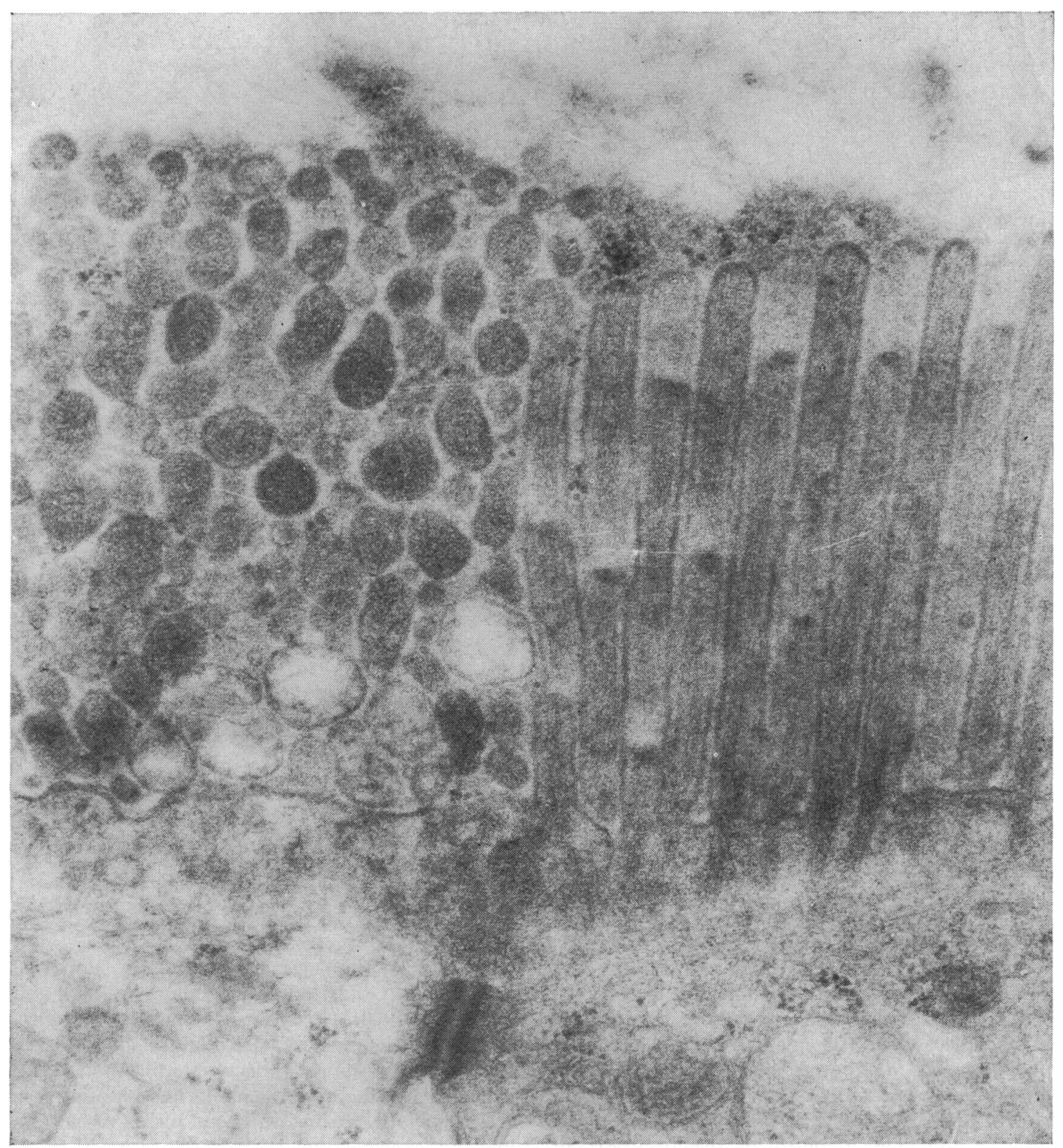

Fig. 4 Higher magnification of junctional area of normal microvilli on the right and abnormal microvilli on the left. The latter are grossly misshapen and have an irregular and abnormal pattern of staining $(\times 50,000)$.

disturbance of bile salt conjugation might be responsible for impaired transport of sugar in these animals. Several groups of workers have shown that unconjugated bile salts impair the intestinal transport of sugars in vitro (Forth, Rummel, and Glasner, 1966; Pope, Parkinson, and Olson, 1966;
Gracey et al, 1971a). In a previous study in blindloop rats (Baraona et al, 1968) and in the present one deconjugated bile salts were found in intestinal contents in association with impaired carbohydrate absorption in vitro. The recent demonstration that the inhibitory effect of these substances is acutely 
reversible (Gracey et al, 1971a) in a newly described system in vitro (Semenza and Mülhaupt, 1969) overcomes the earlier criticism that the inhibitory effect demonstrated in vitro might simply be due to irreversible tissue damage (Dietschy, 1967) and points to the probable relevance of this effect in situations in vivo. The importance of this effect in vivo has recently been confirmed by other experiments from this laboratory where perfusions of the unconjugated bile salts, cholate and deoxycholate, in normal rats have been clearly shown to have an inhibitory effect on intestinal sugar absorption in vivo (Gracey, Burke, and Oshin, 1971b). It is important to recall that the ability of intestinal bacteria to deconjugate bile salts is almost entirely confined to anaerobes (Hill and Draser, 1968). It seems most likely, then, that in the present studies the large numbers of anaerobic bacteria found within the intestinal lumen and possessing this ability, mainly Bacteroides sp. and Bifidobacteria, have led to deconjugation of bile salts which resulted in impaired intestinal transport of monosaccharides.

What is the significance of the ultrastructural changes found in the microvilli and mitochondria of the small intestine of these blind-loop animals? Remarkably similar morphological changes have been demonstrated by Shiner (1969) by instilling deconjugated bile salt into the upper gut of normal rats in vivo and subsequently examining the intestine by electron microscopy. Although the present electron-microscope studies are of limited extent they indicate that ultrastructural changes may occur together with bacterial contamination of the upper small intestine. This view is at variance with the reported findings of previous light- (Donaldson, 1965) and electron-microscope studies (Kjaerheim and Nygaard, 1968), although Paulley (1969) has presented evidence of morphological damage to brush borders of villous tips in patients and experimental animals with bacterial overgrowth in the small intestine. Clearly, more thorough examination of this question is needed in future studies.

This work was supported by grants from the Medical Research Council and the Endowment Fund of the United Birmingham Hospitals. We are grateful to Dr A. H. Cameron for the light-microscope studies and to Professors Charlotte M. Anderson and A. L. d'Abreu and Dr K. B. Rogers for the use of their facilities.

\section{References}

Alvarado, F., and Crane, R. K. (1964). Studies on the mechanism of intestinal absorption of sugars. VII. Phenylglycoside transport and its possible relationship to phlorizin inhibition of the active transport of sugars by the small intestine. Biochim. biophys. Acta (Amst.), 93, 116-135.
Baraona, E., Palma, R., Navia, E., Salinas, A., Orrego, H., and Espinoza, J. (1968). The Role of unconjugated bile salts in the malabsorption of glucose and tyrosine by everted sacs of jejunum of rats with the "blind-loop syndrome'. Acta physiol. lat-amer., 18, 291-297.

Bihler, I., and Crane, R. K. (1962). Studies on the mechanism of intestinal absorption of sugars. V. The influence of several cations and anions on the active transport of sugars, in vitro, by various preparations of hamster small intestine. Biochim. biophys. Acta (Amst.), 59, 78-93.

Burke, V., and Anderson, C. M. (1966). Sugar intolerance as a cause of protracted diarrhoea following surgery of the gastrointestinal tract in neonates. Aust. paediat. J., 2, 219-227.

Burke, V., and Danks, D. M. (1966). Monosaccharide malabsorption in young infants. Lancet, 1, 1177-1180.

Cameron, D. G., Watson, G. M., and Witts, L. J. (1949). The experimental production of macrocytic anaemia by operations on the intestinal tract. Blood, 4, 803-815.

Coello-Ramírez, P., Gutierres-Topete, G., and Lifshitz, F. (1970). Pneumatosis intestinalis. Amer. J. Dis. Child., 120, 3-9.

Crane, R. K., and Mandelstam, P. (1960). The active transport of sugars by various preparations of hamster intestine. Biochim. biophys. Acta (Amst.), 45, 460-476.

Dietschy, J. M. (1967). Effects of the bile salts on intermediate metabolism of the intestinal mucosa. Fed. Proc., 26, 1589-1598.

Donaldson, R. M. Jr. (1965). Studies on the pathogenesis of steatorrhoea in the blind-loop syndrome. J.clin. Invest., 44, 1815-1825.

Donaldson, R. M. Jr. (1967). Role of enteric microorganisms in malabsorption. Fed. Proc., 26, 1426-1431.

Folin, O., and Ciocalteu, V. (1929). On tyrosine and tryptophane determination in proteins. J. biol. Chem., 73, 627-650.

Forth, W., Rummel, W., and Glasner, H. (1966). Zur resorptionshemmenden Wirkung von Gallensäuren. Naunyn-Schmiedeberg's Arch. exp. Path. Pharmak., 254, 364-380.

Goldstein, F., Karacadag, S., Wirts, C. W., and Kowlessar, O. D. (1970). Intraluminal small-intestine utilization of d-xylose by bacteria. A limitation of the d-xylose absorption test. Gastroenterology, 59, 380-386.

Gracey, M., Burke, V., and Anderson, C. M. (1969). Association of monosaccharide malabsorption with abnormal smallintestinal flora. Lancet, 2, 384-385.

Gracey, M., Burke, V., and Oshin, A. (1970). Intestinal transport of fructose. Lancet, 2, 827-828.

Gracey, M., Burke, V., and Oshin, A. (1971a). Reversible inhibition of intestinal active sugar transport by deconjugated bile salt in vitro. Biochim. biophys. Acta (Amst.), 225, 308-314.

Gracey, M., Burke, V., and Oshin, A. (1971b). The effect of bile salts on intestinal sugar transport in vivo. Scand. J. Gastroent., 6, 273-276.

Harries, J. T., and Francis, D. E. M. (1968). Temporary monosaccharide intolerance. Acta paediat. scand., 57, 505-511.

Hill, M.J., and Drasar, B.S. (1968). Degradation of bile salts by human intestinal bacteria. Gut, 9, 22-27.

Hyden, S. (1955). A turbidometric method for the determination of higher polyethylene glycols in biological materials. Kungl. Lantbruk. Ann. Sweden, 22, 139-145.

van de Kamer, J. H., ten Bokkel, Huinink, H., and Weyers, H. A. (1949). Rapid method for the determination of fat in feces $J$. biol. Chem., 177, 347-355.

Kjaerhaim, §., and Nygaard, K. (1968). Fat absorption in rats with an intestinal blind segment. An electron microscopic study. Scand. J. Gastroent. 3, 225-233.

Krebs, H. A., and Henseleit, K. (1932). Untersuchungen über die Harnstoff bildung im Tierkörper. Hoppe-Seylers Z. physiol. Chem., 210, 33-66.

Lifshitz, F., Coello-Ramirez, P., and Gutierrez-Topete, G. (1970a). Monosaccharide intolerance and hypoglycemia in infants with diarrhea.I. Clinical course of 23 infants. J. Pediat., 77, 595-603.

Lifshitz, F., Coello-Ramirez, P., and Gutíerrez-Topete, G. (1970b). Monosaccharide intolerance and hypoglycemia in infants with diarrhea. II. Metabolic studies in 23 infants. J. Pediat., 77, 604-612.

Lowry, O. H., Rosebrough, N. J., Farr, A. L., and Randall, R. J. (1951). Protcin measurement with the Folin phenol reagent. J. biol. Chem., 193, 265-275.

de Man, J. C., Rogosa, M., and Sharpe, M. E. (1960). A medium for the cultivation of lactobacilli. J. appl. Bact., 23, 130-135.

Paulley, J. W. (1969). The jejunal mucosa in malabsorptive st ates with high bacterial counts. In Malabsorption, edited by R. H. Gird- 
wood and A. N. Smith, pp. 171-181. University of Edinburgh Press.

Poley, J. R., Dower, J. C., Owen, C. A. Jr., and Stickler, G. B. (1964). Bile a cids in infants and children.J. Lab. clin. Med., 63, 838-846.

Pope, J. L., Parkinson. T. M., and Olson, J. A. (1966). Action of bile salts on the metabolism and transport of water-soluble nutrients by perfused rat jejunum in vitro. Biochim. biophys. Acta (Amst.), 130, 218-232.

Semenza, G., and Mülhaupt, E. (1969). Studies on intestinal sucrase and sugar transport VII. A method for measuring intestinal uptake. The absorption of the anomeric forms of some monosaccharides. Biochim. biophys. Acta (Amst.), 173, 104-112.

Shiner, M. (1969). Effect of bile acids on the small intestinal mucosa in Man and rats; a light and electron microscopic study. In Bile Salt Metabolism, edited by L. Schiff, J. B. Carey, and J. Dietschy (Conference, Cincinnati, 1967), pp. 41-55. Thomas, Springfield, Illinois.

Sjövall, J. (1959). The determination of bile acids in bile and duodenal contents by quantitative chromatography: Bile acids and steroids. 71. Clin. chim. Acta, 4, 652-664.

Waravdekar, V. S., and Saslaw, L. D. (1957). A method of estimation of 2-deoxyribose. Biochim. biophys. Acta (Amst.), 24, 439.

Wharton, B., Howells, G., and Phillips, I. (1968). Diarrhoea in Kwashiorkor Brit. med. $J ., 4,608-611$.

Zetterström, R., and Waldenström, J. (1968). Familial monosaccharide malabsorption. Mod. Probl. Pädiat., 11, 101-112. 